\title{
Racial Identity in Post-Apartheid South Africa: J.M. Coetzee's Disgrace
}

Roshni Joyson

PG and Research Department of English

Fatima Mata National College (Autonomous)

Kollam, Kerala, India

Dr. Cynthia Catherine Michael

Associate Professor and Head

PG and Research Department of English

Fatima Mata National College (Autonomous)

Kollam, Kerala, India

cynthiamichael2006@yahoo.com

Abstract

J.M. Coetzee is a South African novelist, critic and an active translator of Dutch and Afrikaans literature. His novels are conspicuous for their well- crafted composition, pregnant dialogues and analytical brilliance. Coetzee's earlier novels question the apartheid regime, while his later works offer an apocalyptic vision of post- apartheid South Africa. His major works include Disgrace, Waiting for the Barbarians, Life and Times of Michael K, Boyhood, Age of Iron and The Childhood of Jesus. In 1999, Coetzee has been the recipient of numerous awards throughout his career, although he has a reputation for avoiding award ceremonies. Coetzee became the first author to be twice awarded the Booker Prize, winning it as second time for Disgrace which portrays the post-apartheid society. Coetzee went on to win the Nobel Prize 
for literature in 2003 for his entire body of works. During the years of apartheid, he was at the forefront of the anti-apartheid movement among writers. Scholar Isadore Dalia labelled J.M Coetzee as one of the most distinguished white writers with an anti-apartheid sentiment. Coetzee's earlier novels question the apartheid regime, while his later works offer an apocalyptic vision of post- apartheid South Africa. Disgrace can be analyzed as a representative work of the new south Africa where the social problems relating binary oppositions such as black- white, white- immigrant, powerless- powerful, are stressed. This paper attempts to show through the protagonist, David Lurie, that the way to adapt to the changes in the country is to make a fresh start, a way to adapt to the new times, where no ideas of the old are retained. Frantz Fanon's concepts within the field of post colonialism which he articulated in Black Skin, White Masks (1967) and The Wretched of the Earth (1963) have much relevance in Disgrace. The objective of this paper is to stretch his new ideas in a new direction by applying his theories on nation and culture onto a white subject Lurie, a white native South African. In the light of Fanon's text, The Wretched of the Earth it can be argued that following the revolutionary political changes in South Africa in 1994, the former colonizer can be seen in the same way as the colonized usually is: a powerless native, regardless of racial identity. Keywords: colonizer, colonized, racial identity, marginalization

Disgrace revolves around the life of David Lurie, a professor from Cape Town. Being separated from his wife, Lurie satiates his sexual needs by frequenting a brothel. He finds Soraya, a black prostitute, quite satisfactory. With her departure, he pursues a student, Ms. Melanie Isaacs and forces her into a sexual relationship. When the college authorities become aware of this. they hold a trial for Lurie. He refuses to apologize for his actions and is sent away in disgrace. He goes to his daughter Lucy's farm as a guest and there he gets acquainted with her life style, looking after the farm and the kennel. Lurie also takes up work under Bev 
Shaw, a friend of Lucy's who runs an animal welfare clinic. He helps dispose the bodies of the animals that are euthanized and in so doing cultivates a deep attachment to them. During his stay, Lucy and Lurie fall victims to the brutality of three black men. Lucy is raped and Lurie is left maimed. Lucy becomes distant from her father and the incident; even so, it was the attack that helped to bring solace into their corrupted and confusing relationship. Lucy on discovering her pregnancy, decides to marry her neighbor Petrus purely for reasons of safety. The incidents in the novel are set in post-apartheid south Africa where the social, economic, cultural and political equations of the apartheid era are rewritten. Lurie's transformation from an egoistic macho to a compassionate man conscious of his responsibilities, can be seen to follow Frantz Fanon's theory about the three revolutionary phases in the development of national culture for the colonized. In the light of Fanon's text, The Wretched of the Earth it can be argued that following the revolutionary political changes in South Africa in 1994, the former colonizer can be seen in the same way as the colonized usually is: a powerless native, regardless of racial identity. What is witnessed in Disgrace is a white native in search of the culture of his new nation.

Apartheid was a political and social system of racial segregation in South Africa while it was under white minority rule. The South National Liberation Movement, the American National Congress and its Allies, characterize the South African social formation as a system of internal colonialism or "colonialism of a special type". What is special or different about the colonial system in South Africa is that there is no spatial separation between the colonizing power (the white minority state) and the colonized black people. But in every respect, the features of classic colonialism like economic exploitation and unequal power relationships on racial grounds form the hallmark of the relations between the black majority and white minority. 
The end of apartheid rule was invariably accompanied by a change in the dynamics between the blacks and whites resulting from the contestation of a form of colonial domination and its legacies. The Afrikaneer minority who enjoyed prominence till then lost their place in society. The blacks started holding a position equal to or in some cases above that of the white folks.

The stage of development in the works of colonized writers is labelled the assimilationist phase by Chidi Amuta in his article "Fanon, Cabral and Ngugi on National Liberation". It is described by Fanon as the phase when the colonized intellectual proves he has assimilated the colonizer's culture. (The Wretched of the Earth, 159). For Lurie, an expert in romantic poetry, Byron is seen as a role model. Even their lives have several touching points of which the two most obvious are their predatory ways around women and the fact that they both have to flee their former life due to sexual scandal.

Lurie's position as a white native in South Africa makes him a hybrid; he is English but not British, only South African. At the same time as Lurie turns his creative side to a typical western forum he understands that the new times ahead will bring unavoidable changes. Lurie's feeling of alienation is also understood in a specific socio-political context. The political changes in South Africa make him feel lost in his own country, so he turns to the traditions of the imperial culture, a culture in which he was indoctrinated as an honorary member, as a colonial. This is something natural, Fanon explains; since all colonized people share an inferiority complex through the deprivation of their local cultural originality, and therefore they find themselves "face to face with the language of the civilizing nation; that is, with the culture of the mother country(Black Skin White Masks, 18)". 
Coetzee also makes a point out of Lurie's incapability to adjust to the situation due to his male sex and his role of superior within the power structure of South Africa under apartheid. Lurie's world view is revealed in his discussion with Lucy on her choice of lifestyle, which include voluntary work at the Animal Welfare Clinic, and having best friends without an academic degree. Lucy mocks her father when she says: "you think I ought to be painting still lives or teaching myself Russian. You don’t approve of friends like Bev and Bill Shaw because they are not going to lead me to a better life (Coetzee 74)". On another occasion, Lucy's indignant comment challenges her father's polarized view: "well, contrary to what you think, people are not divide into major and minor (198)". Lurie's own feeling of superiority is shown in the fact that his shameful dismissal in the end is the result of his refusal to acknowledge his fault publicity and to take part in counselling: I'm not prepared to be reformed. I want to go on being myself(77)”.

Since the colonized produces replicas of the dominant culture, there is no progress or development in any direction. Fanon states that "after a century of colonial domination culture becomes rigid in the extreme, congealed and petrified. The atrophy of national reality and the death throes of national culture feed on one another (172)". This is also true of Lurie's mind, temperament and life. He is fully aware of this when he reflects on his dislike of women who: 
Make no effort to be attractive. It is a resistance he had to Lucy's friend before. Nothing to be proud of: a prejudice that has settled down. His mind has become a refuge for old thoughts, idle, indigent, with nowhere else to go. He ought to chase them out, sweep the premises clean. But he does not care to do so or does not care enough. (Coetzee72)

The second phase of Fanon's theory, when "the colonized has his convictions shaken and decides to cast his mind back" (159). In other words, the native intellectual remembers his authentic identity and kicks against attempts to assimilate him. Lurie, who already fights his dubious feelings towards English as medium for the telling of the stories of the new South Africa, clearly is affected by his own hybridity. Representing white natives in South Africa means that he is in an ambiguous position where he is still colonized by Europe and European ideas.

The political changes in South Africa make Lurie reevaluate his representation as a once colonizing member of society. Hybridity reserves the rules of identification that the dominant discourse applies on the colonized, when the rejected knowledge of the colonized intervenes, thus alienating this basis of authority. The power shift in contemporary South African society will have an all- pervading impact on Lurie.

The understanding is shown in his reflections on the English Language and its role as a colonial repressor for native South Africans: "He would not mind Petrus' story one day. But preferable not reduced to English. More and more he is convinced that English is an unfit medium for the truth of South Africa.... Like a dinosaur expiring and setting in the mud, the language has stiffened" (117). This can also be found in Fanon's assertion that "To speak means to be in a position to use a certain syntax, to grasp the 
morphology of this or that language, but it means above all to assume a culture, to support the weight of a civilization" (Black Skin 17-18)

Post-Apartheid South Africa was the site of anarchy and constant violence. This state of chaos ensued from the attempts made by the blacks to regain their status which was mercilessly suppressed for several decades. The build-up of a sense of inadequacy and inferiority in the colonized's psyche, argues Fanon, results in violence, which is a form of selfassertion. Violence was used a means to acquire a position in the society which was hitherto occupied by the whites. In fact, their acts of brutality are a reflection of the mentality shown by the Europeans during apartheid.

In the case of Lurie, the definite break with what has been comes with the attack on Lucy's farm where Lurie is beaten and set on fire, while Lucy is being gang-raped by three black men. Everything that he has believed in concerning himself and the world around him up till that day, changes. He already felt that his power and authority had been decimated when he had to leave his life in Cape Town, even though his self-esteem was intact, holding his head high. But the pointless he and Lucy experience results in the insight that whatever power he had is now completely wiped out. He could not even act on instinct to protect his own child. For the first time in his life, he has suffered entirely on behalf of the fact that he represented the apartheid regime. This fact can best be seen in the only information about her experience of violation that Lucy unwillingly reveals to her father, the significant detail that the men who raped her did so in a frighteningly familiar and personal manner: "It was so personal.... It was done with such personal hatred. That was what stunned me more than anything. The rest was expected. But why did they hate me so? I have never set eyes on them" (Coetzee 156). This insight casts new light on Lurie's sense of self and on his conception of other. He wonders where his place is in this new state and if he has to change in order to fit in. 
According to Fanon, this break with the past in the second phase does not mean that the cultural production changes in any revolutionary way. This phase begins when the colonized realizes that he has something else to contribute with than what the colonial society presumes.

Land dispossession was one of the central poitical- economic issues of the apartheid system but restitution promised the redress of such loss. It enabled former land holders to reclaim spaces and territories that formed the basis of earlier identities and livelihoods. Petrus, a significant character, is a black who once worked as a "dog man" for Lucy in her farm. With the collapse of apartheid, Petrus progressed from his post as assistant to co-proprietor of the farm. The colonizers no longer hold any power over the natives. He is a steady worker and eventually earns considerable wealth. Even when Petrus is suspected of having alliance with the people who raped Lucy, she and Lurie are left helpless unable to even ban him from their farm. As Lucy remarks, "He is not some hired laborer whom I can sack because I my opinion he is mixed with the wrong people. That's all gone, Gone with the Wind" (133). After Lucy discovers of her pregnancy, she decides to sell her land to Petrus and to be accepted under his shelter as his mistress. Petrus desires "subjection" and "subjugation" from Lucy (159). His stance goes to show that the psychic deformations and injuries left behind by racism and colonialism cannot be mended merely by material reparation or by simply reversing economic and political power- structure: 
But isn't there another way of looking at it, David? What if ... What if that is the prize one has to pay for staying on? Perhaps this is how they look at it: they see me as owing something. They see themselves as debt collectors, tax collectors. Why should I be allowed to live here without paying? Perhaps this is what they tell themselves. (158)

The rape incident can be interpreted as "a convergence of the racist sexist thinking about the black body, which has always projected onto the black body a hyper sexuality”. Many of the eighteenth and nineteenth century racist sexist stereotypes attributed to black males are traits that are today considered to be the mark of psychopaths. In Lurie's frustration over Petrus' silence regarding the identity of the rapist and his inability to come up in Lurie's view with a reasonable explanation of his absence during the attack, Lurie says:

In the old days one could have had it out with Petrus. In the old days one could have had it out to the extent of losing one's temper and sending him packing and hiring someone in his place. But though Petrus is paid a wage, Petrus is no longer, strictly speaking, hired help. It is hard to say what Petrus is strictly speaking. The word that seems to serve best, however, is neighbor.... He sells his labor under contract, unwritten contract, and that contract makes no provision for dismissal on grounds of suspicion. It is a new world they live in, he and Lucy and Petrus. Petrus knows it and he knows it, and Petrus knows that he knows it. (116-117)

The excerpt reveals that Lurie, even though he recognizes that times have changed, is still trapped in the glories and privileges of the past and laments that he cannot act as he used 
to in the good old days. His repetition of "in the old days" connotes nostalgia about the past and registers his desire to reverse the hands of the clock. Hence, he laments the loss of the privilege that would have made it possible for him "to take it out with Petrus" even to "the extent of losing (his) temper and sending him packing". The problem with Lurie is that even though he recognizes that times have changed and indeed notes that "it is a new world", he refuses to come to terms with it. Thus even though he is aware that the old hegemony of master and slave has disrupted, and in fact remarks that "knows it, and Petrus knows that he knows it, he stubbornly clings to the past (116-117). Therefore, Lurie struggles to maintain the old dynamics of racial superiority and domination of the apartheid era.

The first element of the apartheid's damage was that all involved parties have been affected in one way or another by the strife, untold suffering and injustice of the recent past of violence on human beings by human beings. In some way or the other, all were victims: victims of the apartheid system. The truth and reconciliation commission, a court like restorative justice body assembled in South Africa after the abolition of apartheid in the 1990s, was emphatic in their stance that the apartheid was to be judged as a far more heinous act, as a crime against humanity. The truth and reconciliation commission was a process of bearing witness to the past, with a view of producing, among other things, recognition of the mutuality of violation and suffering under apartheid. One of the most remarkable features of the commission was the insistence that the country bear witness to gross human rights violations across the board, from those committed within the apartheid regime to those of the liberation struggle.

This was in no way to render all these violations morally comparable. This has to go hand in hand with the recognition of different types of victimhood, each associated with varying degrees of trauma and suffering. The result is that there is a collapse of certain binaries 
especially in the dyadic categories of victims and perpetrators. It is no longer possible to demarcate people and categorize one set as the victims and the other as perpetrators. They are not readily separable or well-bounded. An example of this blurring of categories can be seen in the case of Petrus. He starts out as a "dogman" or an assistant to Lucy, a white woman. Later when the apartheid system ends, he becomes co-owner of the farm with Lucy. As the dogman, he is a victim; a victim of the apartheid system which denied him rights to the land on which he worked. But when he turns a blind eye towards the rape of Lucy he becomes a perpetrator. Lurie's new found compassion in his fellow creatures enables him even to put himself in the position of animals, especially dogs- the lowest valued of all South African domestic animals. The nationalist phase, which is called "combat stage" by Fanon, is the phase "where the colonized writer, after having tried to lose himself among the people, with the people, will rouse the people. Combat literature, national literature, revolutionary literature emerges" (159). For Lurie, this third phase begins when he realizes that the sacrifices and changes he has made are not enough.

The future lies in the next generation of South Africans, with the Lucies and the Petruses: "I suspect it's too late for me. I'm just an old rag serving out my sentence. But you go ahead. You are well on the way," he tells Lucy(216).Lurie's thoughts can be read as representing the future nation of South Africa, as can be seen in the following where he ponders the fact that he will become a grandfather:

What will it entail, being a grandfather? As a father he has not been much of a success, despite trying harder than most. As a grandfather he will probably score lower than average too. He lacks the virtues of the old: equanimity, kindness, 
patience. But perhaps those virtues will come as others virtues go: the virtue of passion. (217-218) 


\section{Works Cited}

The wretched of the earth. Trans. Richard Philcox. New York: Grove Press, 1963.

Fanon, Franz. Black Skin, White Masks. Trans. Richard Philcox. New York: Grove Press, 1952.

Wilson, Richard A. The Politics of Truth and Reconciliation in South Africa: Legitimizing the Post-Apartheid State. UK: CUP,2001.

Attwell, David. Interview with J.M. Coetzee" Web. 22 Jan. 2016. http://www.dn.se/kulturnoje/an-exclusive-interview-with-j-m-coetzee.

Amuta Chidi. "Fanon, Cabral and Ngugi on National Liberation". Across the Lines: Intertextuality and Transcultural Communication in the New Literatures in English. Ed. Wolfgang Kloos. Netherlands: Rodopi,1998. 